\title{
Prevalence of Bovine Trypanosomosis and Apparent Density of Tsetse Flies in Sayonole District Western Oromia, Ethiopia
}

\section{Bedaso Kebede Kassaye*}

Veterinary Drug and Animal Feed Administration and Control Authority, Ministry of Agriculture, Addis Ababa, Ethiopia

*Corresponding author: Bedaso Kebede Kassaye, Veterinary Drug and Animal Feed Administration and Control Authority, Ministry of Agriculture, Addis Ababa, Ethiopia, Tel: 0913136824; E-mail: Kebede.bedaso@yahoo.com

Rec date: Jul 21, 2015; Acc date: Aug 18, 2015; Pub date: Aug 20, 2015

Copyright: ( 2015 Kassaye. This is an open-access article distributed under the terms of the Creative Commons Attribution License, which permits unrestricted use, distribution, and reproduction in any medium, provided the original author and source are credited.

\begin{abstract}
A cross-sectional study was carried out from January up to March 2013 to determine the prevalence of bovine Trypanosomosis and apparent density of the tsetse flies and other biting flies in Sayonole district. The methods employed during the study were deploying trap for the collection of tsetse flies and buffy coat technique for parasitological study. About 43 traps were deployed for $48 \mathrm{hr}$ for collection of tsetse fly. Among five species of tsetse flies commonly found in Ethiopia four of them G.m.submorsitans, G.pallidepes, G.f.fuscipes and G.tachinoides were captured in the study area. The overall apparent density of tsetse flies trapped was $13.01 \mathrm{flies} /$ trap/day and female tsetse flies were foremost in number. Other biting flies caught were Stomoxys and Tabanus. Blood samples collected randomly from 599 cattles were assessed for trypanosoma species by buffy coat techniques. Trypanosoma species faced in the study area were Trypanosoma congolense 80(79.2\%), Trypanosoma vivax 11(10.9\%), mixed infection (Trypanosoma congolense and Trypanosoma vivax) 10(9.9\%) with the overall Trypanosomosis prevalence of $16.9 \%$. Aneamic cattles whichPacked Cell Volume less than $25 \%$ were mainly endangered of Trypanosomosis and significantly different $\mathrm{P}<0.05$. Poor body condition, $4-5$ years of cattle age, Male cattle were the most susceptible for Trypanosomosis and insignificantly associated $P>0.05$. Mean of Overall, Aparasitic and Parasitic Packed Cell Volume were $22.38 \pm 5.022,22.68 \pm 4.966$ and $20.86 \pm 5.044$ respectively and significantly different $\mathrm{P}<0.05$.Generally, the study concludes that tsetse flies were an important vector for the epidemiology of bovine Trypanosomosis in sayonole district. Therefore, Vector and disease control and prevention methods and further studies should be undertaken to improve livestock production and productivity in the study area.
\end{abstract}

Keywords: Prevalence; Trypanosomosis; Tsetse flies; Cattle; Sayonole district

\section{Introduction}

Trypanosomosis is the most serious veterinary and animal production problem in sub-Saharan Africa and prevents the keeping of ruminants and equines over 10 millions of square kilometers of potentially productive land. Hence, this study is the road map and contribution to the Pan African Tsetse and Trypanosomosis Eradication Campaign agenda [1]. It is a protozoal disease caused by different species of unicellular parasites found in the blood and other tissues of vertebrates including livestock, wild life and people [2]. Bovine trypanosomosis is one of the diseases that are caused by flagellated protozoan parasites belong to the genus Trypanosoma. Trypanosomosis limit the extension of natural herds particularly in Africa where the presence of tsetse fly density access to wood land and savannah areas with good grazing potential $[3,4]$. It is a serious constraint to agricultural production in extensive areas of the tsetse infested regions [5]. The traction power of African agriculture $80 \%$ is provided by animals which were reduced capacity of work by Trypanosomes infection [3]. Generally, there is a great threat of trypanosomosis which impedes the economic development of African continent and also reasonable for the incalculable toll of human health [6]. Currently six species of trypanosomes are recorded in Ethiopia and the most important trypanosomes in terms of economic loss in domestic livestock are the tsetse transmitted species: Trypanosoma congolense, Trypanosoma vivax and Trypanosoma brucei [3].
Tsetse flies in Ethiopia are confined to southwestern and northwestern regions between longitude $33^{\circ}$ and $38^{\circ} \mathrm{E}$ and latitude $5^{\circ}$ and $12^{\circ} \mathrm{N}$ covers an area of $220,000 \mathrm{~km}^{2}$ [7]. Tsetse infested areas lie in the low lands and also in the river valleys of Abay (Blue Nile), Baro, Akobo, Didessa, Ghibe, and Omo [8]. Consequently, new areas are being invaded and settled communities are being continually evicted by the advancing tsetse. Five species of Glossina ( $G$. morsitans submorsitans, G. pallidipes, G. tachinoides, G. fuscipes fuscipes and $G$. longipennis) have been recorded in Ethiopia [3]. Apart from the cyclical transmission of trypanosomosis by the Glossina species, it is highly considered that mechanical transmission is a potential threat to livestock productivity in some parts of Ethiopia [3]. Annual report of National Tsetse and Trypanosomosis Investigation and Control Center indicated that tsetse transmitted animal trypanosomosis is still remain as one of the largest causes of livestock production losses in Ethiopia [7]. In Sayonole district trypanosomosis was found to be one of the factors that slowed down livestock rearing in most of its peasant associations. However, hard evidence on the occurrence of tsetse and trypanosomosis in the area is lacking $[9,10]$.

Therefore, the objectives of the present study were to determine the prevalence bovine trypanosomosis and to assess the distribution and apparent density of its vectors in Sayonole district of Western Oromia, Ethiopia. 


\section{Materials and Methods}

\section{Study area, population and sample size}

The study was conducted from January up to March 2013 in Sayonole district, Western Oromia, which is situated at $500 \mathrm{Km}$ West of Addis Ababa. The mean annual rain fall in Sayonole district ranges from $1000-1500 \mathrm{~mm}$. The annual temperature ranges from $15-31^{\circ} \mathrm{C}$. The areas have got a number of wild animals, such as African buffaloes, Bush pigs, warthog, bush buck, kudu, hippopotamus, crocodiles, hyena, antelopes and snakes which are claimed to serve as sources of food for the vector of trypanosomes.

The cattle in the district are local breeds that are kept under traditional extensive husbandry systems with communal herding. Agriculture is the main livelihood of the society with mixed farming system and livestock play an integral role for agriculture. The district has 18 peasant associations and animal population estimated to be 122,985 cattle, 10,540 sheep, 16,933 goats, and 1,203 donkeys in 2012.

The sampling method applied was simple random sampling. The sample size was calculated at $95 \%$ confidence interval, $50 \%$ expected prevalence and $5 \%$ precision. The required sample size was 384 cattle; however, a total of 599 cattle were sampled to increase the precision [11].

\section{Study design and protocol}

Sayo nole district was selected purposely based on the extent of the existing problems of Trypanosomosis, the complaints of farmers and the level of medium to high tsetse challenge in the area. A crosssectional study design was employed and three peasant associations were selected based on the veterinarian and farmers reports of the Trypanosomosis and tsetse infestation in the district. The cattle were categorized into three age categories $1-3$ years, $4-5$ years and $\geq 6$ years and three categories of body condition of Good, Medium and Poor. For the trypanosomosis prevalence study buffy coat techniques were used. Blood sample collection was performed by piercing the marginal ear vein with a sterile lancet and blood was drawn by a heparinized capillary tube. Then one end (the heparanized end) of capillary tubes were sealed with crystal sealant and centrifuged at 12,000 rpm for five minutes to separate the blood cells and to concentrate trypanosomes using centrifugal forces. Then the PCV was determined by PCV reader and recorded. The capillary tubes were then broken just below buffy coat using diamond pencil and expressed on microscopic slide and covered with a cover slip. It was examined under $40 \times$ objective of microscope to identify and detect the presence of the parasites [12].

The entomological survey consists of a total of 43 mono pyramidal baited traps which were the most important to catch riverine species and deployed in riparian and savannah that are suitable areas for tsetse habitats to assess the apparent densities, distributions and species of tsetse flies and other biting flies involving in transmission of trypanosomosis. All traps were baited with acetone, octenol (1-3octane) and cow urine filled in separated bottles and labeled and deployed at an interval of 200-250 m. After $48 \mathrm{hr}$ or 2 days of trap deployment the cages were collected and captured flies were identified and sexed according to morphological characteristics and counted. The tsetse flies were identified to species level and the other biting flies to the genus level. The apparent density elements were the amount of flies collected from the traps deployed, number of the traps deployed and period of deployment in days and it is calculated as the number of flies collected/functional trap/period of deployment in days [6].

\section{Data management and analysis}

Raw data were entered into a Microsoft Excel spreadsheet and descriptive statistics were used to summarize the data. The prevalence was calculated for all data as the number of infected individuals divided by the number of individuals examined and multiplied by 100 . The association between the prevalence of trypanosome infection and risk factors were assessed by chi-square, whereas the student's t-test was used to assess the difference in mean Packed Cell Volume between trypanosome positive, negative and overall examined animals. All statistical analyses were conducted using SPSS version 20.0 software. The test result was considered significant when the calculated p-value was less than 0.05 . The apparent density of fly population was calculated by dividing the number of flies caught by the number of traps deployed and the number of days of deployment and expressed as fly/trap/day (FTD).

\section{Results}

\section{Entomological survey result}

In the study area tsetse flies $G$. morsitans submorsitans, $G$. pallidipes, $G$. fuscipes and $G$. tachnoides and other biting flies were trapped. The overall apparent density 13.01 flies/trap/day of the tsetse flies in Sayonole district. Among Glossina species caught riverine species G. fuscipes fuscipes was the dominant 9.2 flies/trap/day followed by savannah species G. pallidipes 3.6flies/trap/day in the study area. Sex identification performed on 1,119 tsetse flies caught in the study area and counted. The male and female sexes were 503 and 616 respectively. Abichu peasant association was high in infestation of tsetse flies (30.31 F/T/D). However, Gutemikael peasant association has no infestation of tsetse flies. Biting flies Stomoxys and Tabanus were caught (Table 1).

\begin{tabular}{|c|c|c|c|c|c|c|c|c|c|c|c|c|c|c|c|}
\hline \multirow[t]{3}{*}{$\begin{array}{l}\text { Peasant } \\
\text { Association }\end{array}$} & \multirow[t]{3}{*}{$\begin{array}{l}\text { Altitude } \\
\text { range of } \\
\text { Trap } \\
\text { deployed }\end{array}$} & \multicolumn{10}{|c|}{$\begin{array}{l}\text { Tsetse } \\
\text { flies } \\
\text { caught }\end{array}$} & \multicolumn{4}{|c|}{ Biting flies caught } \\
\hline & & \multicolumn{2}{|c|}{ G.m.submorsitans } & \multicolumn{2}{|c|}{ G. pallidipes } & \multicolumn{2}{|c|}{ G. f. fuscipes } & \multicolumn{2}{|c|}{ G. tachnoides } & \multirow{2}{*}{\begin{tabular}{|l|} 
Total \\
No. \\
\end{tabular}} & \multirow{2}{*}{$\begin{array}{l}\text { FTD } \\
\mathrm{f} / \mathrm{t} / \mathrm{d}\end{array}$} & \multicolumn{2}{|c|}{ Stomoxys } & \multicolumn{2}{|c|}{ Tabanus } \\
\hline & & M & $F$ & M & $\mathbf{F}$ & M & $\mathbf{F}$ & M & $\mathbf{F}$ & & & No. & $f / t / d$ & & \\
\hline Abichu & $1420-1445 m$ & 1 & 1 & 3 & 18 & 390 & 357 & 18 & 0 & 788 & 30.31 & 110 & 4.23 & 6 & 0.46 \\
\hline Korekokir & $1391-1435 m$ & 0 & 0 & 77 & 210 & 14 & 30 & 0 & 0 & 331 & 11.03 & 189 & 6.3 & 3 & 0.2 \\
\hline
\end{tabular}


Citation: Kassaye BK (2015) Prevalence of Bovine Trypanosomosis and Apparent Density of Tsetse Flies in Sayonole District Western Oromia, Ethiopia . J Veterinar Sci Technol 6: 254. doi:10.4172/2157-7579.1000254

Page 3 of 6

\begin{tabular}{|l|l|l|l|l|l|l|l|l|l|l|l|l|l|l|l|}
\hline Gutemikael & $1545-1691 \mathrm{~m}$ & 0 & 0 & 0 & 0 & 0 & 0 & 0 & 0 & 0 & 0 & 103 & 3.43 & 2 & 0.13 \\
\hline Total & & 1 & 1 & 80 & 228 & 404 & 387 & 18 & 0 & 1119 & 13.01 & 402 & 4.67 & 11 & 0.26 \\
\hline
\end{tabular}

Table 1: Distribution and apparent density of tsetse flies according to peasant associations. F/T/D=flies/trap/day, M=Male, F=Female, G.m.submorsitan=G. morsitans submorsitans, G. f. fuscipes = G. fuscipes fuscipes.

\section{Trypanosomes survey results}

Composition of cattle involved in the study were 1-3 years old male (73), 1-3 years old female (67), 4-5 years old male (152), 4-5 years old female (126), and $\geq 6$ years old male (131), $\geq 6$ years old female (50). Blood samples collected from those 599 cattle were centrifuged and examined under microscope. The examination revealed that Trypanosoma congolense 80(79.2\%), Trypanosoma vivax 11(10.9\%), mixed infection of Trypanosoma congolense and Trypanosoma vivax 10(9.9\%) and null infection of Trypanosoma brucei and finally two trypanosomes species were the causes of Bovine Trypanosomosis in the study area (Table 2). The overall prevalence of Trypanosomosis in Sayonole district was $16.9 \%$. Abichu peasant association was high in prevalence of Trypanosomosis $25.83 \%$ (Table 3 ). The prevalence of Trypanosomosis on aneamic cattles $(\mathrm{PCV}<25 \%)$ was $70(18.5 \%)$ due to the infection of Trypanosoma congolense 61(16.1\%), Trypanosoma vivax $2(0.5 \%)$ and mixed infection of Trypanosoma congolense and Trypanosoma vivax was $7(1.9 \%)$ and significantly different $\mathrm{P}<0.05$ with prevalence of trypanosomosis (Table 4). Prevalence of Trypanosomosis is frequent on poor body condition score $40(19.7 \%)$ followed by medium body condition score $21(18.5 \%)$ and insignificantly associated $\mathrm{P}=0.324$ with the body condition score (Table 5). Trypanosomosis prevalence of cattles with the age categories of 4-5, $1-3$ and $\geq 6$ years were 52(18.8\%), 26(18.5\%) and 23(12.7\%) and insignificantly associated with age $\mathrm{P}=0.282$ (Table 6 ). Trypanosomosis prevalent on male cattles $69(19.4 \%)$ than female cattles $32(13.1 \%)$ and insignificantly associated with sex $\mathrm{P}=0.117$ (Table 7).

\begin{tabular}{|l|l|l|}
\hline \multirow{2}{*}{ Trypanosoma species } & \multicolumn{2}{|l|}{ Prevalence of Trypanosoma } \\
\cline { 2 - 3 } & Frequency & Percent \\
\hline T.C. & 80 & 79.2 \\
\hline T.V. & 11 & 10.9 \\
\hline Mixed infection & 10 & 9.9 \\
\hline Total & 101 & 100 \\
\hline
\end{tabular}

Table 2: Prevalence of Trypanosoma species. T.C.=Trypanosoma congolense, T.V.=Trypanosoma vivax, Mixed infection=T.C. \&T.V.

\begin{tabular}{|c|c|c|c|c|c|c|}
\hline \multirow[t]{2}{*}{ Peasant Associations } & \multirow[t]{2}{*}{ Sample size } & \multirow[t]{2}{*}{ Non infected } & \multicolumn{4}{|c|}{ Prevalence of Trypanosomosis } \\
\hline & & & T.C. & T.V. & Mixed infection & Total \\
\hline Abichu & 240 & $178(74.2 \%)$ & $48(20 \%)$ & $9(3.8 \%)$ & $5(2.1 \%)$ & $62(25.83 \%)$ \\
\hline Kore kokir & 199 & $160(80.4 \%)$ & $32(16.1 \%)$ & $2(1.0 \%)$ & $5(2.5 \%)$ & $39(19.6 \%)$ \\
\hline Gute mikael & 160 & $160(100 \%)$ & 0 & 0 & 0 & 0 \\
\hline Total & 599 & $498(83.1 \%)$ & $80(13.4 \%)$ & $11(1.8 \%)$ & $10(1.7 \%)$ & $101(16.9 \%)$ \\
\hline
\end{tabular}

Table 3: Prevalence of Trypanosomosis in three peasant associations. T.C.=Trypanosoma congolense, T.V=Trypanosoma vivax, Mixed infection=T.C. \&T.V.

\begin{tabular}{|c|c|c|c|c|c|c|c|c|}
\hline \multirow[t]{2}{*}{ PCV value } & \multirow[t]{2}{*}{ Sample size } & \multirow[t]{2}{*}{ Non infected } & \multicolumn{4}{|c|}{ Prevalence of Trypanosomosis } & $X^{2}$-value & P-value \\
\hline & & & T.C. & T.V. & $\begin{array}{l}\text { Mixed } \\
\text { infection }\end{array}$ & Total & \multirow{3}{*}{$16.014 a$} & \multirow{3}{*}{0.001} \\
\hline$<25$ & 378 & $308(81.5 \%)$ & $61(16.1 \%)$ & $2(0.5 \%)$ & $7(1.9 \%)$ & $70(18.5 \%)$ & & \\
\hline$\geq 25$ & 221 & $190(86 \%)$ & $19(8.6 \%)$ & $9(4.1 \%)$ & $3(1.4 \%)$ & $31(14 \%)$ & & \\
\hline Total & 599 & $498(83.1 \%)$ & $80(13.4 \%)$ & $11(1.8 \%)$ & $10(1.7 \%)$ & $101(16.9 \%)$ & & \\
\hline
\end{tabular}

Table 4: Comparison prevalence of Trypanosomosis in Aneamic or non-Aneamic cattles. T.C.=Trypanosoma congolense, T.V.=Trypanosoma vivax, Mixed infection=T.C. \&T.V.

\begin{tabular}{|l|l|l|l|l|l|}
\hline BCS & Sample size & Non infected & Prevalence of Trypanosomosis & $X^{2}$-value & P-value \\
\hline
\end{tabular}


Citation: Kassaye BK (2015) Prevalence of Bovine Trypanosomosis and Apparent Density of Tsetse Flies in Sayonole District Western Oromia,

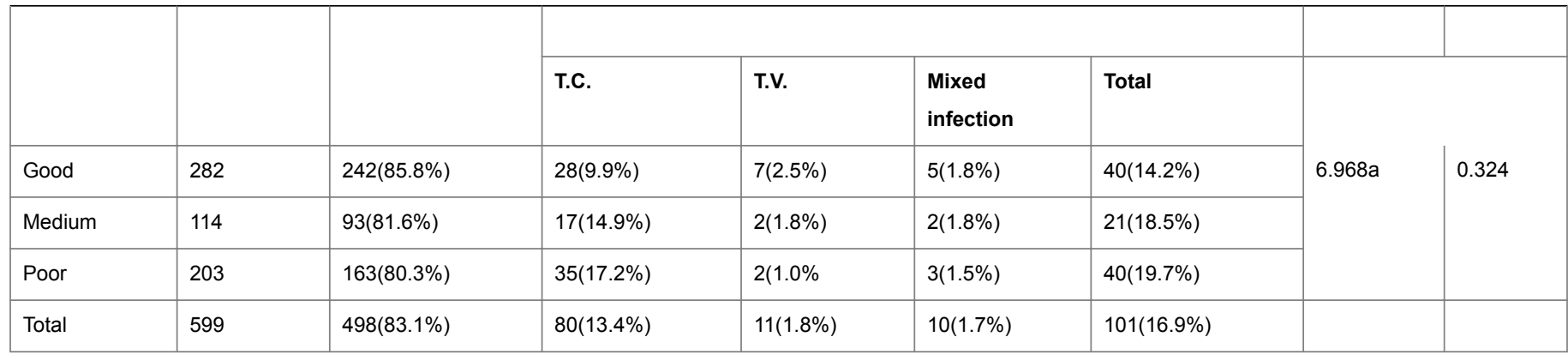

Table 5: Prevalence of Trypanosomosis by body condition score (BCS). T.C.=Trypanosoma congolense, T.V.=Trypanosoma vivax, Mixed infection=T.C. \&T.V.

\begin{tabular}{|c|c|c|c|c|c|c|c|c|}
\hline \multirow{2}{*}{$\begin{array}{l}\text { Age in } \\
\text { year }\end{array}$} & \multirow[t]{2}{*}{ Sample size } & \multirow[t]{2}{*}{ Non infected } & \multicolumn{4}{|c|}{ Prevalence of Trypanosomosis } & $X^{2}$-value & P-value \\
\hline & & & T.C. & T.V. & $\begin{array}{l}\text { Mixed } \\
\text { infection }\end{array}$ & Total & \multirow{4}{*}{$7.445 a$} & \multirow{4}{*}{0.282} \\
\hline $1-3$ & 140 & $114(81.4 \%)$ & $24(17.1 \%)$ & $1(0.7 \%)$ & $1(0.7 \%)$ & $26(18.5 \%)$ & & \\
\hline $4-5$ & 278 & $226(81.3 \%)$ & $40(14.4 \%)$ & $6(2.2 \%)$ & $6(2.2 \%)$ & $52(18.8 \%)$ & & \\
\hline$\geq 6$ & 181 & $158(87.3 \%)$ & $16(8.8 \%)$ & $4(2.2 \%)$ & $3(1.7 \%)$ & $23(12.7 \%)$ & & \\
\hline Total & 599 & $498(83.1 \%)$ & $80(13.4 \%)$ & $11(1.8 \%)$ & $10(1.7 \%)$ & $101(16.9 \%)$ & & \\
\hline
\end{tabular}

Table 6: Prevalence of Trypanosomosis by age.T.C.=Trypanosoma congolense, T.V.=Trypanosoma vivax, Mixed infection=T.C. \&T.V.

\begin{tabular}{|c|c|c|c|c|c|c|c|c|}
\hline \multirow[t]{2}{*}{ Sex } & \multirow[t]{2}{*}{ Sample size } & \multirow[t]{2}{*}{ Non infected } & \multicolumn{4}{|c|}{ Prevalence of Trypanosomosis } & $X^{2}$-value & P-value \\
\hline & & & T.C. & T.V. & $\begin{array}{l}\text { Mixed } \\
\text { infection }\end{array}$ & Total & \multirow{3}{*}{$5.883 a$} & \multirow{3}{*}{0.117} \\
\hline Female & 244 & $212(86.9 \%)$ & $28(11.5 \%)$ & $2(0.8 \%)$ & $2(0.8 \%)$ & $32(13.1 \%)$ & & \\
\hline Male & 355 & $286(80.6 \%)$ & $52(14.6 \%)$ & $9(2.5 \%)$ & $8(2.3 \%)$ & $69(19.4 \%)$ & & \\
\hline Total & 599 & $498(83.1 \%)$ & $80(13.4 \%$ & $11(1.8 \%)$ & $10(1.7 \%)$ & $101(16.9 \%)$ & & \\
\hline
\end{tabular}

Table 7: Prevalence of Trypanosomosis by sex. T.C.=Trypanosoma congolense, T.V.=Trypanosoma vivax, Mixed infection= T.C. \&T.V.

\section{Haematological survey result}

Blood samples collected from cattles were centrifuged by heamatocrit centrifuge and its PCV read by PCV reader. Mean of
Overall, Aparasitic and Parasitic PCV were $22.38 \pm 5.022,22.68 \pm$ 4.966 and $20.86 \pm 5.044$ respectively and significantly associated $\mathrm{P}<0.05$ (Table 8).

\begin{tabular}{|l|l|l|l|l|l|l|l|l|l|l|}
\hline Categories & Sample size & Mean & Std. Deviation & $\begin{array}{l}\text { Std. Error } \\
\text { Mean }\end{array}$ & T-test & df & Mean difference & $\begin{array}{l}\text { P-value } \\
\text { in\% } \\
\text { interval } \\
\text { difference }\end{array}$ & $\begin{array}{l}\text { Confidence } \\
\text { of } \\
\text { the }\end{array}$ \\
\hline Overall PCV & 599 & 22.38 & 5.022 & 0.205 & 109.059 & 598 & 22.377 & 0.000 & 21.97 \\
\hline Aparasitic PCV & 498 & 22.68 & 4.966 & 0.223 & 101.936 & 497 & 22.685 & 0.000 & 22.25 & 23.12 \\
\hline
\end{tabular}




\begin{tabular}{|l|l|l|l|l|l|l|l|l|l|l|}
\hline Parasitic PCV & 101 & 20.86 & 5.044 & 0.502 & 41.566 & 100 & 20.861 & 0.000 & 19.87 & 21.86 \\
\hline
\end{tabular}

Table 8: Mean of Packed Cell Volume (PCV) of Overall, Aparasitic and Parasitic cattles. PCV=Packed Cell Volume, df=degree of freedom.

\section{Discussion}

In the present study four species of Glossina G.m.submorsitans, G.pallidepes, G.tachinoides and G.f.fuscipes were caught and 13.01 flies/trap/day of apparent density was recorded in Sayonole district. Other biting flies Stomoxys and Tabanus were caught. This study agrees with the apparent density of tsetse flies 14.97 flies/trap/day in selected villages of Arbaminch by Teka [13]. This study result is greater than study report from Mandura district, Northwest Ethiopia with 0.06 flies/trap/day apparent density of tsetse flies by Lelisa, et al. [14]. However, it is slightly lower than the finding reported by Ayele, et al. [15] of 19.14 flies/trap/day apparent density. The apparent density of tsetse flies in Sayonole district is huge because no control activities have taken yet. For this reason, it has gotten a favorable condition for the tsetse flies to multiply in the area. In this finding more female tsetse flies were caught than male tsetse flies which comply with finding of Efrem, et al. [16] in Lalo kile district, Kellem Wollega zone. This could be because of the female tsetse flies physiologically necessitated to feed more animal blood during pregnancy than males which exposes it to trapping than male tsetse flies.

The study revealed that the overall prevalence of Trypanosomosis from 599 cattles sampled in Sayonole district was $16.9 \%$. It was slightly consistent with the finding of $13.44 \%$ Waktole [17] in Gawo Dale district Kellem Wollega zone and $20.74 \%$ of Mekuria, et al. [18] from Metekel zones. However, it was greater than the findings of $6.86 \%$ Efrem, et al. [14] in Lalo Kile district of Kellem Wollega zone; $6.9 \%$ Alamayehu et al. [15] in Chena district, South west Ethiopia and 5.43\% Lelisa, et al. [14] in Mandura District, Northwest Ethiopia which were reported. The higher prevalence of trypanosomosis in this study may be endorsed to the lack of application of control measures such as target impregnated insecticides, insecticide treatment of cattle and regular treatment of sick animals [19].

The prevalent Trypanosoma species in the study area was Trypanosoma congolense $80(79.2 \%)$. It was marginally reliable with the finding in the Lalo kile district 75\% reported by Efrem, et al. [16] and $84 \%$ in Ghibe by Muturi [20]. Even though, it was higher than other areas studies in southern Ethiopia $37 \%$ by Rowlands et al. [21]; $58.5 \%$ in tsetse infested areas of the country Abebe and Jobre [4]; $66.17 \%$ in Southern Rift Valley Rowlands et al. [22]; 71.8\% in the Gawo Dale district Waktole [20] and 72.3\% in Gawo Dale District [6]. Anaemia $(\mathrm{PCV}<25 \%)$ was dominant by infection of Trypanosoma congolense $61(16.1 \%)$ than other species of Trypanosoma. The predominance of Trypanosoma congolense infection in cattle may be due to the high number of serodems of $\mathrm{T}$. congolense as compared to $\mathrm{T}$. vivax and the development of better immune response to $\mathrm{T}$. vivax by the infected animal [23].

Trypanosomosis was prevalent on the poor body condition scored $40(19.7 \%)$ cattles. This finding is similar to the report by Bacha et al. [24]; Daya, Abebe [24]; Teka, et al. [12] and Lelisa et al. [14]. So, poor body condition cattles are less immune to infection than medium and good body condition score cattles.

This study indicates that Trypanosomosis prevalent in male cattle 69(19.4\%) than female cattle 32(13.1\%). Different workers reported that higher prevalence was observed in male cattle than in female ones Afewerk [25]; Tewelde [26] and Muturi [20].The possible suggestion to this finding could be that male cattles are more used for draught purposes, travel long distances to an area of tsetse challenge for grazing or plowing and stressed by draught power and as a result the risk of contracting trypanosomosis is higher.

In this study a higher infection rate was observed in age categories of $4-5$ years $52(18.8 \%)$. This could be associated to the fact that majority cattles of age 4-5years are productive which travel long distance for grazing and draught as well as harvesting crops in areas of high to tsetse challenge. In the results of Rowlands et al. [22] in Ghibe valley indicated that suckling calves donot go out with their dams but graze at home steads until they are weaned off. Young animals are also naturally protected to some extent by maternal antibodies report of Fimmen et al. [27]. This could result in low prevalence in calves and also Trypanosoma congolense infection is a chronic disease increasing with age of animals. Infection by Trypanosoma congolense is usually higher in adult animals than young according to Mc Dermott et al. $[28,29]$.

The overall mean of Packed Cell Volume (PCV) value of examined cattle was $22.38 \pm 5.022$ and significantly different $\mathrm{P}<0.05$. The mean PCV of Aparasitic cattle was higher $22.68 \pm 4.966$ than parasitic cattle $20.86 \pm 5.044$. In fact the difference in mean PCV between parasitaemic cattles and Aparasitaemic cattles indicated that trypanosomosis may be involved in adversely lowering the PCV values of infected animals. Parasitaemic cattles had generally lower mean PCV than the corresponding Aparasitaemic cattles. Though, there is appearing of parasitological negative cattles within the PCV values of less than the threshold value. This may be due to inadequacy of detection method as Murray [12] or delayed recovery of anaemic situation after current treatment with trypanocidal drugs and may be other blood parasites infection, malnutrition associated with long draught in the areas. While the occurrences of positive animals with PCV greater than or equal to $25 \%$ might be thought of recent infection of animals.

\section{Conclusion and Recommendations}

The results of the present study revealed that Glossina species are the most responsible for the spread of bovine trypanosomosis in the study area which is the most important problem for agricultural activity and improvement of animal production and productivity. According to entomological survey result in the Sayonole district four species of tsetse flies G.f.fuscipes, G.tachinoides, G.m.submorsitans and G.pallidepes and other biting flies Tabanus and Stomoxys were captured. Parasitological survey result shows that Trypanosoma congolense, Trypanosoma vivax and mixed infection of both was identified in the study area and Trypanosoma congolense was the dominant trypanosomes species identified in the area. In case of heamatological survey result $\mathrm{PCV}<25 \%$ was principal on poor body condition score cattles. The situation of bovine trypanosomosis in the area is getting worse as no activities of the control and prevention of trypanosomosis was taken place in the Sayonole district. 
Therefore, Designing and implementation of control strategies of trypanosomosis focusing on sustainable, community based, simple, cost effective, environmentally friendly and integrated approach should be undertaken and Proper and strict follow-up of trypanocidal drugs treatment should be conducted in the Sayonole district western Oromia, Ethiopia.

\section{Acknowledgment}

I am indebted to the Bedelle Regional Veterinary Laboratory center and its entire staff member for financial and technical support during this study.

\section{References}

1. WHO (2001) the Pan African Tsetse and Trypanosomosis Eradication Campaign (PATTEC). Plan action.

2. Uilenberg G (1998) A field guide for the diagnosis, treatment and prevention of African animal trypanosomosis. Food and Agriculture Organization of the United Nations, Rome.

3. Abebe G (2005) Review Article: Trypanosomosis in Ethiopia. Ethiop J Biol Sci 4:75-121.

4. Abebe G and Jobre Y (1996) Trypanosomosis. A threat to cattle production in Ethiopia. Rev Med Vet 147: 897- 902.

5. Slingenebergh J (1992) Tsetse control and agricultural development in Ethiopia. World Anim Rev 70-71: 30 -36.

6. Leak SKA, Woume KA, Colardelle C, Duffera W, Feron A, et al. (1987) Determination of tsetse challenge and its relationship with trypanosomosis prevalence. In: Livestock production in tsetse infested areas of Africa. Nairobi, Kenya, ATLN, p: 43-52.

7. National Tsetse and Trypanosomosis Investigation and Control Center (2004) Annual report on Tsetse and Trypanosomosis survey. Bedelle, Ethiopia.

8. Langridge WP (1976) Tsetse and Trypanosomosis survey of Ethiopia. Ministry of overseas Department, UK, Pp: 1-40.

9. Cecchi G, Paone M, Argilés Herrero R, Vreysen MJ, Mattioli RC (2015) Developing a continental atlas of the distribution and trypanosomal infection of tsetse flies (Glossina species). Parasit Vectors 8: 284.

10. Cecchi G, Paone M, Feldmann U, Vreysen MJ, Diall O, et al. (2014) Assembling a geospatial database of tsetse-transmitted animal trypanosomosis for Africa. Parasit Vectors 7: 39.

11. Tewelde N (2001) Study on the occurrence of drugresistant trypanosomes in cattle in the farming intsetse control areas (FITCA) project in western, Ethiopia, MSc thesis Addis Ababa University, Faculty of Veterinary Medicine Debre Zeit, Ethiopia, pp: 1-98.

12. Murray M, Murray PK, McIntyre WIM (1977) An improved parasitological technique for the diagnosis of African trypanosomosis. Transactions of the Royal Society of Tropical Medicine and Hygiene 71: 325-326.

13. AyeleT, Ephrem D, Elias K, Tamiru B, Gizaw D, et al. (2012) Prevalence of Bovine Trypanosomosis and its vector density in Daramallo district, Southwestern Ethiopia. J vet adv 6:266-272.
14. Teka W, Terefe D, Wondimu A (2012) Prevalence study of Bovine Trypanosomosis and Tsetse Density in selected villages of Arbaminch, Ethiopia. Journal of Vet Med And Anim Health 4: 36-41.

15. Lelisa K, Damena D, Kedir M, Feyera T (2015) Prevalence of Bovine Trypanosomosis and Apparent Density of Tsetse and other Biting flies in Mandura district, Northwest,Ethiopia. Journal of Vet Scie And Techn 6:229.

16. Efrem D, Bashatu F, Bacha B, Addisalem H, Misgana D (2013) Prevalence of Bovine Trypanosomosis in Lalo Kile district, Kelem Wollega Zone, Oromia regional state, Western Ethiopia. Acta Parasitologica Globalis 4: $34-40$.

17. Alemayehu B, Bogale B, Fentahun T, Chanie M (2012) Bovine trypanosomosis: A threat to cattle production in Chena district, Southwest Ethiopia. Open Journal of Ani Scie 2: 287-291.

18. Mekuria S, Gadissa F (2011) Survey on bovine trypanosomosis and its vector in Metekel and Awi zones of Northwest Ethiopia. Acta Trop 117: 146-151.

19. Fimmen HO, Mehlitz D, Horchiner F, Korb E (1992) Colostral antibodies and Trypanosoma congolense infection in calves.Trypanotolerance research and application. GTZ, No.116, Germany 57: 173-187.

20. McDermott J, Woitag T, Sidibé I, Bauer B, Diarra B, et al. (2003) Field studies of drug-resistant cattle trypanosomes in Kénédougou Province, Burkina Faso. Acta Trop 86: 93-103.

21. Rowlands GJ, Mulatu W, Authié E, d'Ieteren GD, Leak SG, et al. (1993) Epidemiology of bovine trypanosomiasis in the Ghibe valley, southwest Ethiopia. 2. Factors associated with variations in trypanosome prevalence, incidence of new infections and prevalence of recurrent infections. Acta Trop 53: 135-150.

22. Waktole TE (2008) Studies on bovinetrypanosomosis and therapeutic efficacy of selected trypanocidal drugs in Birbir valley of GawoDalledistrict, West Oromia, MSc Thesis Addis Ababa University, Faculty of Veterinary Medicine Debre Zeit, Ethiopia.

23. Muturi KS (1999) Epidemiology of bovine trypanosomosis in selected sites of the Southern Rift valley of Ethiopia, MSc thesis, Faculty of veterinary medicine, Addis Ababa University.

24. Rowlands GJ, Mulatu W, Nagda SM, Dolan RB, d'Ieteren GDM (1995) Genetic variation in packed red cell volume andfrequency of parasitaemia in East African Zebucattle exposed to drug resistant trypanosomes. Liv Prod Sci 43: 75-84

25. Bacha B, Beyene Z, Woyessa M, Hunde (2013) Prevalence of Small Ruminants Trypanosomosis in Assosa District of Benishangul Gumuz Regional State, Western Part of Ethiopia. Acta Parasitologica Globalis 4: 99-104.

26. Daya T, Abebe G (2008) Seasonal dynamics of tsetse and trypanosomosis in selected sites of Ethiopia. Ethiop Vet J 12: 77-98.

27. Afewerk Y (1998) Field investigation on theappearance of drug resistant population oftrypanosomes in Metekel District, North-WestEthiopia, MSc thesis, Addis Ababa University andFreieUniverstat Berlin, Faculty of VeterinaryMedicine, Ethiopia.

28. Thrusfield M (1995) Veterinary Epidemiology, (2nd Edn) Blackwell Science Ltd, UK. Pp: 182-198.

29. Leak S, GA (1999) Tsetse Biology and Ecology: Their role in the Epidemiology of Trypanosomosis. CAB International, Nairobi, Kenya. 